\title{
Effect of replacing grass silage with red clover silage on nutrient digestion, nitrogen metabolism, and milk fat composition in lactating cows fed diets containing a 60:40 forage-to-concentrate ratio
}

\author{
A. Halmemies-Beauchet-Filleau, ${ }^{*} \dagger$ A. Vanhatalo, $\dagger$ V. Toivonen, ${ }^{*}$ T. Heikkilä, ${ }^{*}$ M. R. F. Lee, $\ddagger^{1}$ \\ and K. J. Shingfield ${ }^{* 2}$ \\ ${ }^{*}$ MTT Agrifood Research Finland, Animal Production Research, FI-31600 Jokioinen, Finland \\ †University of Helsinki, Department of Agricultural Sciences, PO Box 28, Fl-00014 University of Helsinki, Finland \\ fInstitute of Biological, Environmental and Rural Sciences, Aberystwyth University, Gogerddan, Aberystwyth, Ceredigion, \\ SY23 3EB, United Kingdom
}

\section{ABSTRACT}

Diets based on red clover silage (RCS) typically increase the concentration of polyunsaturated fatty acids (PUFA) in ruminant meat and milk and lower the efficiency of $\mathrm{N}$ utilization compared with grass silages (GS). Four multiparous Finnish Ayrshire cows (108 d postpartum) fitted with rumen cannulas were used in a $4 \times 4$ Latin square design with 21 -d periods to evaluate the effect of incremental replacement of GS with RCS on milk production, nutrient digestion, whole-body $\mathrm{N}$ metabolism, and milk fatty acid composition. Treatments comprised total mixed rations offered ad libitum, containing $600 \mathrm{~g}$ of forage $/ \mathrm{kg}$ of diet dry matter (DM), with RCS replacing GS in ratios of 0:100, 33:67, 67:33, and 100:0 on a DM basis. Intake of DM and milk yield tended to be higher when RCS and GS were offered as a mixture than when fed alone. Forage species had no influence on the concentration or secretion of total milk fat, whereas replacing GS with RCS tended to decrease milk protein concentration and yield. Substitution of GS with RCS decreased linearly whole-tract apparent organic matter, fiber, and $\mathrm{N}$ digestion. Forage species had no effect on total nonammonia $\mathrm{N}$ at the omasum, whereas the flow of most AA at the omasum was higher for diets based on a mixture of forages. Replacing GS with RCS progressively lowered protein degradation in the rumen, increased linearly ruminal escape of dietary protein, and decreased linearly microbial protein synthesis. Incremental inclusion of RCS in the diet tended to lower whole-body $\mathrm{N}$ balance, increased linearly the proportion of dietary $\mathrm{N}$ excreted in feces and urine, and decreased linearly the utilization of dietary $\mathrm{N}$ for milk protein synthesis. Furthermore, replacing GS with

Received August 9, 2013.

Accepted February 10, 2014.

${ }^{1}$ Current address: School of Veterinary Science, University of Bristol, Langford, Somerset, BS40 5DU, United Kingdom.

${ }^{2}$ Corresponding author: kevin.shingfield@mtt.fi
RCS decreased linearly milk fat 4:0 to 8:0, 14:0, and 16:0 concentrations and increased linearly $18: 2 \mathrm{n}-6$ and 18:3n-3 concentrations, in the absence of changes in cis-9 18:1, cis-9,trans-11 18:2, or total trans fatty acid concentration. Inclusion of RCS in the diet progressively increased the apparent transfer of 18-carbon PUFA from the diet into milk, but had no effect on the amount of $18: 2 n-6$ or $18: 3 n-3$ at the omasum recovered in milk. In conclusion, forage species modified ruminal $\mathrm{N}$ metabolism, the flow of $\mathrm{AA}$ at the omasum, and whole-body $\mathrm{N}$ partitioning. A lower efficiency of $\mathrm{N}$ utilization for milk protein synthesis with RCS relative to GS was associated with decreased availability of AA for absorption, with some evidence of an imbalance in the supply of AA relative to requirements. Higher enrichment of PUFA in milk for diets based on RCS was related to an increased supply for absorption, with no indication that forage species substantially altered PUFA bioavailability.

Key words: red clover, grass, milk fatty acid, nitrogen metabolism

\section{INTRODUCTION}

Red clover (Trifolium pratense) is a common forage legume grown in northern Europe, the United States, and Canada. Forage legumes form an integral part of organic and low-input milk-production systems, owing to the ability to capture atmospheric $\mathrm{N}_{2}$, lowering the necessity for additional N. Given the rising costs of inorganic $\mathrm{N}$ fertilizers and attempts to decrease the environmental footprint of ruminant livestock production, red clover may also be advantageous in conventional milk-production systems. Compared with grasses, red clover has a high intake and milk-production potential (Dewhurst et al., 2003b; Moorby et al., 2009; Steinshamn, 2010), but the efficiency of dietary N utilization for milk protein synthesis is often lower (Dewhurst et al., 2003b; Moorby et al., 2009; Vanhatalo et al., 2009). It has been postulated that either an excessive or an 
imbalanced supply of AA available to the mammary glands, or possibly both, may limit the conversion efficiency of dietary $\mathrm{N}$ into milk with red clover silage (RCS) diets, with a potential deficiency of Met being implicated (Lee et al., 2009; Vanhatalo et al., 2009).

Meat and milk from ruminants are characterized by high concentrations of SFA and a low abundance of PUFA, due at least in part, to extensive biohydrogenation of dietary unsaturated FA in the rumen (Dewhurst et al., 2003a; Shingfield et al., 2013). Ruminant-derived foods are an important source of lipid in the human diet (Shingfield et al., 2013) and, therefore, considerable interest exists in developing nutritional strategies to lower 12:0, 14:0, and 16:0 and increase 18:3n-3 in ruminant milk fat with potential to improve long-term human health (Gebauer et al., 2006; Shingfield et al., 2008). It is well established that milk from diets based on RCS contains much higher 18:2n-6 and 18:3n-3 concentrations compared with ensiled grass (Dewhurst et al., 2006; Vanhatalo et al., 2007; Moorby et al., 2009). At least part of the enrichment in milk can be attributed to higher amounts of 18:2n-6 and 18:3n-3 escaping the rumen (Dewhurst et al., 2003a,b), but the influence of forage species on the digestion, absorption, and utilization of FA for milk fat synthesis in lactating cows has not been extensively investigated.

Red clover has a higher polyphenol oxidase (PPO) activity compared with grasses, differences that have been suggested to contribute to the effects of forage species on proteolysis and lipolysis in silo and in vivo (Lee et al., 2004; Merry et al., 2006; Van Ranst et al., 2011). Previous investigations comparing RCS and grass silage (GS) diets have characterized the effects of forage species on ruminal $\mathrm{N}$ and lipid metabolism and milk FA composition in lactating cows under conditions typical for organic or low-input milk production (Dewhurst et al., 2003a,b; Moorby et al., 2009).

The aim of the present study was to provide further insight into the influence of forage species on the transformations of dietary protein in the rumen, efficiency of $\mathrm{N}$ utilization, and bioavailability of FA in cows fed diets relevant to more intensive milk-production systems. Four cows in a $4 \times 4$ Latin square design were used to test the hypotheses that the effects of RCS on the efficiency of $\mathrm{N}$ utilization and milk FA composition are related to changes in the amount and bioavailability of AA and FA available for absorption.

\section{MATERIALS AND METHODS}

\section{Animals, Experimental Design, and Experimental Diets}

All experimental procedures were approved by the National Animal Ethics Committee (Hämeenlinna,
Finland) in accordance with guidelines established by the European Community Council Directives 86/609/ EEC. Four multiparous Finnish Ayrshire cows (599 \pm $26.0 \mathrm{~kg}$ of BW, $108 \pm 5.8 \mathrm{DIM}$, and producing 30.0 $\pm 1.84 \mathrm{~kg}$ of milk/d) fitted with rumen cannulas (100 mm i.d.; Bar Diamond Inc., Parma, ID) were allocated at random to experimental diets according to a $4 \times 4$ Latin square with 21-d periods. A detailed description of experimental treatments, management of grass and red clover leys, and preparation of experimental silages are provided in a companion paper (HalmemiesBeauchet-Filleau et al., 2013c). In brief, experimental treatments comprised TMR containing $600 \mathrm{~g}$ of forage/ $\mathrm{kg}$ of diet DM with RCS replacing GS in the diet in the DM ratio of 0:100, 33:67, 67:33, and 100:0 (treatments GS, GRC, RCG, and RCS, respectively). Silages were prepared from mixed timothy (Phleum pratense L. 'Tuukka') and meadow fescue (Festuca pratensis Huds. 'Antti' and 'Ilmari') and red clover (Trifolium pratense L. 'Jokioinen') swards treated with $5 \mathrm{~L} / \mathrm{t}$ of formic acid-based additive (760 $\mathrm{g}$ of formic acid and $55 \mathrm{~g}$ of ammonium formate, AIV 2 Plus; Kemira Ltd., Helsinki, Finland). Forages were supplemented with a standard concentrate (Table 1). Diets were offered ad libitum as 4 equal meals at 0600,0800, 1800, and $2000 \mathrm{~h}$. The chemical composition of individual feed ingredients and experimental diets is shown in Table 1. Cows were housed in a dedicated metabolism unit fitted with individual tie-stalls with continuous access to water. Cows were milked twice daily at 0700 and $1645 \mathrm{~h}$. At the end of the experiment, cows weighed $603 \pm 29.3 \mathrm{~kg}$.

\section{Measurements and Sampling}

Individual cow intakes were recorded throughout the experiment, but only measurements for the last $7 \mathrm{~d}$ of each period were used for statistical analysis. During this time, representative samples of silage and concentrates were collected, composited, and stored at $-20^{\circ} \mathrm{C}$ before chemical analysis. The chemical composition of feeds, including the correction of silage DM content for volatile losses was determined using standard methods (Halmemies-Beauchet-Filleau et al., 2013a). Starch in feeds was analyzed according to Salo and Salmi (1968). The concentration of indigestible NDF (iNDF) in silages and concentrates was determined in duplicate by incubating 0.5 - to 1 -g samples within polyester bags $(60 \times 120 \mathrm{~mm}, 17-\mu \mathrm{m}$ pore size $)$ in the rumen for 12 d (Ahvenjärvi et al., 2000). The OM content of the indigestible residue was determined by ashing at $600^{\circ} \mathrm{C}$ for $18 \mathrm{~h}$. Body condition scores were recorded on a scale of 1 (thin) to 5 (fat) at the start of the experiment and at the end of each experimental period. 
Table 1. Chemical composition of dietary ingredients and experimental diets

\begin{tabular}{|c|c|c|c|c|c|c|c|}
\hline \multirow[b]{2}{*}{ Item } & \multicolumn{3}{|c|}{ Dietary ingredient } & \multicolumn{4}{|c|}{ Experimental diet ${ }^{1}$} \\
\hline & $\begin{array}{l}\text { Grass } \\
\text { silage }^{2}\end{array}$ & $\begin{array}{l}\text { Red clover } \\
\text { silage }^{3}\end{array}$ & Concentrate $^{4}$ & GS & GRC & $\mathrm{RCG}$ & RCS \\
\hline DM, \% & 23.6 & 23.3 & 89.8 & 50.1 & 50.0 & 50.0 & 49.9 \\
\hline Ash & 8.72 & 10.3 & 5.27 & 7.34 & 7.66 & 7.97 & 8.29 \\
\hline $\mathrm{CP}$ & 15.6 & 20.0 & 20.1 & 17.4 & 18.3 & 19.2 & 20.0 \\
\hline NDF & 52.9 & 33.9 & 22.1 & 40.6 & 36.8 & 33.0 & 29.2 \\
\hline Indigestible NDF & 9.82 & 9.16 & 4.30 & 7.61 & 7.48 & 7.35 & 7.22 \\
\hline Water-soluble carbohydrates & 3.29 & 2.08 & 6.84 & 4.71 & 4.47 & 4.23 & 3.98 \\
\hline Starch & 1.03 & 1.63 & 28.6 & 12.1 & 12.2 & 12.3 & 12.4 \\
\hline \multicolumn{8}{|l|}{$\mathrm{AA}, \mathrm{g} / 100 \mathrm{~g}$ of $\mathrm{CP}$} \\
\hline Arg & 4.25 & 4.72 & 5.66 & 4.90 & 4.97 & 5.04 & 5.10 \\
\hline His & 1.50 & 2.00 & 2.38 & 1.91 & 2.00 & 2.08 & 2.15 \\
\hline Ile & 4.16 & 4.84 & 3.67 & 3.93 & 4.09 & 4.24 & 4.37 \\
\hline Leu & 7.51 & 8.25 & 6.69 & 7.13 & 7.31 & 7.47 & 7.62 \\
\hline Lys & 5.37 & 4.91 & 4.81 & 5.11 & 5.02 & 4.94 & 4.87 \\
\hline Met & 2.41 & 2.15 & 2.30 & 2.36 & 2.30 & 2.26 & 2.21 \\
\hline Phe & 5.02 & 5.31 & 4.26 & 4.67 & 4.75 & 4.82 & 4.89 \\
\hline Thr & 4.45 & 4.73 & 4.01 & 4.25 & 4.32 & 4.38 & 4.44 \\
\hline Val & 5.49 & 7.08 & 4.98 & 5.25 & 5.61 & 5.94 & 6.24 \\
\hline Ala & 6.63 & 6.65 & 4.17 & 5.49 & 5.55 & 5.61 & 5.66 \\
\hline Asp & 9.93 & 11.2 & 6.85 & 8.51 & 8.85 & 9.17 & 9.45 \\
\hline Cys & 1.08 & 1.03 & 2.32 & 1.65 & 1.61 & 1.58 & 1.55 \\
\hline Glu & 10.7 & 10.1 & 18.4 & 14.3 & 14.0 & 13.7 & 13.4 \\
\hline Gly & 4.75 & 5.12 & 4.51 & 4.64 & 4.73 & 4.80 & 4.88 \\
\hline Orn & 1.14 & 0.14 & 0.08 & 0.65 & 0.45 & 0.28 & 0.12 \\
\hline Pro & 5.35 & 4.80 & 6.78 & 6.01 & 5.86 & 5.72 & 5.59 \\
\hline Ser & 4.22 & 4.86 & 4.35 & 4.28 & 4.42 & 4.54 & 4.66 \\
\hline Tyr & 2.79 & 3.41 & 3.01 & 2.89 & 3.02 & 3.14 & 3.25 \\
\hline$\Sigma$ Branched-chain $\mathrm{AA}^{5}$ & 17.2 & 20.2 & 15.3 & 16.3 & 17.0 & 17.7 & 18.2 \\
\hline$\Sigma \mathrm{EAA}^{6}$ & 40.2 & 44.0 & 38.8 & 39.6 & 40.4 & 41.2 & 41.9 \\
\hline$\Sigma \mathrm{NEAA}^{7}$ & 46.6 & 47.3 & 50.5 & 48.4 & 48.5 & 48.5 & 48.6 \\
\hline$\Sigma$ Total AA & 86.8 & 91.3 & 89.2 & 87.9 & 88.8 & 89.7 & 90.5 \\
\hline
\end{tabular}

${ }^{1}$ Refers to diets containing a 60:40 forage:concentrate ratio based on grass silage (GS), red clover silage (RCS), or a 2:1 (GRC) or 1:2 (RCG) mixture (DM basis) of GS and RCS, respectively.

${ }^{2}$ Mean fermentation characteristics of grass silage: $\mathrm{pH} 3.97$; \% of DM: lactic acid: 6.32 , acetic acid: 1.97 , propionic acid: 0.02 , and butyric acid: $0.04 ; \%$ of total N: ammonium-N: 4.46 and soluble N: 61.5 .

${ }^{3}$ Mean fermentation characteristics of red clover silage: $\mathrm{pH} 4.00$; \% of DM: lactic acid: 10.1, acetic acid: 2.49 , propionic acid: 0.02 , and butyric acid: $0.01 ; \%$ of total $\mathrm{N}$ : ammonium-N: 5.28 and soluble N: 38.4.

${ }^{4}$ Concentrate comprised (\% of DM in TMR) rolled barley (18), molassed sugar beet pulp (9), solvent-extracted rapeseed meal (11.5; Raisio Feed Ltd., Raisio, Finland), and a proprietary vitamin and mineral supplement (1.5; Onni; Melica Finland Ltd., Vaasa, Finland) declared as containing (g/kg) calcium (205), magnesium (72), sodium (85), phosphorus (27), zinc (1.46), manganese (0.35), copper (0.27); ( $\mathrm{mg} / \mathrm{kg}$ ) iodine (39), cobalt (27), selenium (20); and (IU/g) retinyl acetate (120), cholecalciferol (25), and DL- $\alpha$-tocopheryl acetate (0.34).

${ }^{5} \mathrm{Sum}$ of Ile, Leu, and Val.

${ }^{6}$ Sum of Arg, His, Ile, Leu, Lys, Met, Phe, Thr, and Val.

${ }^{7}$ Sum of Ala, Asp, Cys, Glu, Gly, Orn, Pro, Ser, and Tyr.

Omasal digesta flow was determined using the omasal sampling technique (Ahvenjärvi et al., 2000) using Cr-EDTA, Yb-acetate, and iNDF as markers for liquid, small particles, and large particles, respectively (Halmemies-Beauchet-Filleau et al., 2013c). Spot samples $(500 \mathrm{~mL})$ of digesta entering the omasal canal were collected 3 times daily at 4-h intervals on d 17 to 20 using the omasal sampling device. Sampling started at 0600 $\mathrm{h}$ and was advanced by $1 \mathrm{~h}$ each day to cover a 12 -h period. Digesta collected over the 12-h interval from 0600 to $1800 \mathrm{~h}$ was considered representative for the entire feeding cycle. At the end of the experiment, digesta samples were separated into large-particle, small-particle, and liquid phases by filtration and centrifugation, freeze-dried, and analyzed for DM, OM, VFA, Cr, Yb, and iNDF (Halmemies-Beauchet-Filleau et al., 2013c). Based on marker concentrations, the relative proportions of the liquid, small-particle, and large-particle fractions in true digesta were calculated (Ahvenjärvi et al., 2000). Thereafter, appropriate amounts of freezedried digesta were weighed to yield a composite sample for chemical analysis. 
The flow of microbial $\mathrm{N}$ at the omasum was estimated using $15.0 \mathrm{~g} / \mathrm{d}$ of ammonium sulfate (Isotec Inc., Miamisburg, OH) enriched (10\%) with ${ }^{15} \mathrm{~N}$ (317 mg of ${ }^{15} \mathrm{~N} / \mathrm{d}$ ) as a marker. Ammonium sulfate was dissolved in the same solution containing Yb-acetate and infused into the rumen from d 15 at 0600 to $1800 \mathrm{~h}$ on d 21 of each period. Immediately before the start of the marker infusion, samples of rumen contents for each cow were collected for the determination of background ${ }^{15} \mathrm{~N}$ abundance. Samples of digesta $(500 \mathrm{~mL})$ for the analysis of microbial ${ }^{15} \mathrm{~N}$ enrichment were collected $(\mathrm{n}=4)$ from the reticulorumen at $1500,1200,0900$, and $0600 \mathrm{~h}$ on d $17,18,19$, and 20, respectively. Microbes were isolated from ruminal digesta by differential centrifugation and filtration (Ahvenjärvi et al., 2000). Enrichment of ${ }^{15} \mathrm{~N}$ in reticulorumen and omasal digesta was analyzed in triplicate using a Roboprep-CN analyzer (Europa Scientific Ltd., Crewe, UK) and VG Micromass 622 mass spectrometer (VG Micromass Ltd., Winsford, UK) according to Esala (1991). Concentrations of AA in feeds and reconstituted omasal digesta were analyzed following acid hydrolysis $\left(6 \mathrm{M} \mathrm{HCl}\right.$ at $110^{\circ} \mathrm{C}$ for $\left.23 \mathrm{~h}\right)$ according to the European Commission (1998) directive using a Waters MassTrak ultra performance liquid chromatography (UPLC) kit (Waters Corp., Milford, MA) and the UPLC AA analysis solution provided by the manufacturer.

Whole-tract apparent digestibility coefficients were determined by total fecal collection over $96 \mathrm{~h}$, starting at $1800 \mathrm{~h}$ on $\mathrm{d} 17$ of each experimental period. Subsamples $(5 \%$, wt $/ \mathrm{wt})$ were stored at $-20^{\circ} \mathrm{C}$ until analyzed for DM, OM, NDF, iNDF, N, Cr, and $\mathrm{Yb}$ using the same methods applied to feeds and omasal digesta.

Milk yield was recorded daily throughout the experiment, but only measurements made from d 15 to 21 of each period were used for statistical analysis. Samples of milk were collected from each cow over 4 consecutive milkings starting at $1645 \mathrm{~h}$ on d 19. Milk samples treated with preservative (bronopol; Valio Ltd., Helsinki, Finland) were analyzed for milk fat, CP, and lactose (MilkoScan 605 analyzer; Foss Electric A/S, Hillerød, Denmark). Samples of unpreserved milk were also collected, stored at $4^{\circ} \mathrm{C}$, composited according to yield, and analyzed for urea concentration, measured as ammonia following urease hydrolysis (Shingfield et al., 2002). Additional samples of unpreserved milk composited according to yield were stored at $-20^{\circ} \mathrm{C}$ until analyzed for FA composition.

\section{Lipid Analysis}

Lipid in 1-mL milk samples was extracted 3 times with a mixture of ammonia, methanol, diethyl ether, and hexane (0.2:1:2.5:2.5, vol/vol, respectively) and converted to FAME using methanolic sodium methoxide as a catalyst (Halmemies-Beauchet-Filleau et al., 2011).

Samples of FAME were quantified using a gas chromatograph (model 6890; Hewlett-Packard, Wilmington, DE) equipped with a flame-ionization detector, automatic injector, split injection port, and a 100-m fused silica capillary column (0.25-mm i.d.) coated with a $0.2-\mu \mathrm{m}$ film of cyanopropyl polysiloxane (CPSil 88, Chromopack 7489; Chromopack, Middelburg, the Netherlands). The total FAME profile in a $2-\mu \mathrm{L}$ sample at a split ratio of 1:50 was determined using a temperature gradient program and hydrogen as a carrier gas operated at constant pressure $(137.9 \mathrm{kPa})$ at a flow rate of $0.5 \mathrm{~mL} / \mathrm{min}$. Isomers of $18: 1$ were further resolved in a separate analysis under isothermal conditions at $170^{\circ} \mathrm{C}$. Peaks were identified by comparison of retention times with authentic FAME standards. Fatty acid methyl esters not available as commercial standards were identified based on GC-MS analysis of 4,4-dimethyloxoline derivatives prepared from FAME. Preparation of 4,4-dimethyloxoline derivatives, parameters used for GC-MS analysis, and interpretation mass spectra were in accordance with earlier reports (Halmemies-Beauchet-Filleau et al., 2011). Relative retention time and order of elution was used to differentiate between diastereomers of 3,7,11,15-tetramethyl-16:0 (Halmemies-Beauchet-Filleau et al., 2013b).

The distribution of CLA isomers in milk samples was determined using an HPLC system (model 1090; Hewlett-Packard, Wilmington, DE) equipped with 4 silver-impregnated silica columns (ChromSpher 5 Lipids, $250 \times 4.6 \mathrm{~mm}, 5-\mu \mathrm{m}$ particle size; Varian Ltd., Walton-on-Thames, UK) coupled in series. Methyl esters of CLA were separated under isothermal conditions at $22^{\circ} \mathrm{C}$ using $0.1 \%$ (vol/vol) acetonitrile in heptane at a flow rate of $1 \mathrm{~mL} / \mathrm{min}$ and monitoring column effluent at 233 and $210 \mathrm{~nm}$ (Halmemies-Beauchet-Filleau et al., 2011).

Milk FA composition was expressed as a weight percentage of total FA using theoretical relative response factors to account for the carbonyl deficiency in the flame-ionization detector response for 4- to 10-carboncontaining FAME (Halmemies-Beauchet-Filleau et al., 2011). Concentrations of specific conjugated isomers were calculated based on proportionate peak area responses determined by HPLC and the sum of trans7,cis-9 CLA, trans-8,cis-10 CLA, and cis-9,trans-11 CLA weight percentage determined by GC.

\section{Calculations}

Metabolizable energy content of experimental diets $(\mathrm{MJ})$ was calculated as $0.016 \times$ digestible $\mathrm{OM}$ in $\mathrm{DM}$ 
(g/kg; Ministry of Agriculture, Fisheries and Food, 1975) determined by total fecal collection.

Ruminal AA balance $(\mathrm{g} / \mathrm{d})$ was calculated as flow of AA at the omasum $(\mathrm{g} / \mathrm{d})$ - intake of AA $(\mathrm{g} / \mathrm{d})$.

Ruminal protein degradability (\%) was calculated as follows: $(\{[\mathrm{N}$ intake $(\mathrm{g} / \mathrm{d})-$ ammonia- $\mathrm{N}$ intake $(\mathrm{g} / \mathrm{d})]-$ flow of dietary NAN at the omasum $(\mathrm{g} / \mathrm{d})\} /[\mathrm{N}$ intake $(\mathrm{g} / \mathrm{d})-$ ammonia-N intake $(\mathrm{g} / \mathrm{d})]) \times 100$.

Ruminal AA degradability (\%) was calculated as follows: $\{$ [intake of AA $(\mathrm{g} / \mathrm{d})$ - flow of dietary AA at the omasum $(\mathrm{g} / \mathrm{d})] /$ intake of AA $(\mathrm{g} / \mathrm{d})\} \times 100$.

Flow of dietary AA at the omasum $(\mathrm{g} / \mathrm{d})$ was calculated as total flow of AA at the omasum $(\mathrm{g} / \mathrm{d})$ - flow of microbial AA at the omasum $(\mathrm{g} / \mathrm{d})$, assuming that AA represented, on average, $73.4 \%$ of microbial NAN entering the omasal canal (Korhonen et al., 2002), and the AA profile of microbial NAN measured across 18 dietary treatments, based on the mean of 43 determinations for cows fed diets based on GS, RCS, or mixtures of both forage species [A. Vanhatalo (University of Helsinki, Helsinki, Finland) and P. Huhtanen (Swedish University of Agricultural Sciences, Umeå, Sweden), unpublished data]. The assumption underlying these calculations was considered valid, given that differences in diet composition have minimal influence on the AA composition of microbial NAN fractions at the omasum (Korhonen et al., 2002).

Whole-body $\mathrm{N}$ balance $(\mathrm{g} / \mathrm{d})$ was calculated as $\mathrm{N}$ intake $(\mathrm{g} / \mathrm{d})-[\mathrm{N}$ in milk $(\mathrm{g} / \mathrm{d})+\mathrm{N}$ excreted in feces $(\mathrm{g} / \mathrm{d})+\mathrm{N}$ excreted in urine $(\mathrm{g} / \mathrm{d})]$.

The transfer efficiency (\%) of FA from the diet into milk was calculated as FA secretion in milk $(\mathrm{g} / \mathrm{d}$ per FA intake; g/d) $\times 100$. Efficiency of transfer $(\%)$ of FA at the omasum into milk was calculated as FA secretion in milk $(\mathrm{g} / \mathrm{d}$ per FA flow at the omasum; $\mathrm{g} / \mathrm{d}) \times 100$.

\section{Statistical Analysis}

Data were analyzed by ANOVA with a model that included the fixed effects of treatment and period and random effects cow using PROC MIXED of SAS (version 9.2; SAS Institute Inc., Cary, NC). Sums of squares for treatment effects were further separated using orthogonal contrasts into single-degree-of-freedom comparisons to test for the significance of linear and quadratic components of response to incremental replacement of GS with RCS in the diet. Least squares means are reported, with treatment effects declared significant at $P \leq 0.05$, with $P$-values between 0.05 and 0.10 considered a trend toward significance. Relationships between flows of FA at the omasum and the secretion of FA in milk were evaluated by linear regression analysis using PROC REG of SAS.

\section{RESULTS}

\section{Nutrient Intake}

Intakes of DM, OM, starch, and $\mathrm{N}$ tended $(P \leq 0.08)$ to be higher when RCS and GS were offered together than when fed as the sole forage in the diet (Table 2). Increases in the proportion of RCS in the diet decreased linearly $(P<0.01)$ NDF intake (Table 2$)$. Replacing GS with RCS in the diet increased linearly $(P<0.01)$ AA intake from 3,175 to $3,600 \mathrm{~g} / \mathrm{d}$ (Supplemental Table S1; http://dx.doi.org/10.3168/jds.2013-7358). The intake of most AA increased linearly $(P<0.05)$ in response to RCS in the diet, except that of Cys, Glu, Lys, Met, and Pro, which were unaffected $(P>0.10)$ by differences in forage species, whereas Orn decreased linearly $(P<$ 0.01) to RCS in the diet (Supplemental Table S1).

\section{Omasal Flow of Nutrients}

Increases in the proportion of RCS in the diet decreased linearly $(P<0.05)$ the flow of $\mathrm{OM}$ and NDF at the omasum (Table 2). Treatments had no effect $(P>0.10)$ on total NAN at the omasum. However, substituting GS for RCS in the diet decreased linearly $(P<0.01)$ microbial NAN, but increased linearly $(P<$ 0.01 ) dietary NAN at the omasum (Table 2). Feeding mixtures of GS and RCS increased $(P<0.05$; Met, Phe, Val, Pro, and Ser), or tended to increase $(P \leq$ 0.10; Arg, His, Leu, Thr, Ala, Glu, and Gly) the flow of most AA at the omasum compared with either forage species alone (Table 2).

\section{Nutrient Digestibility}

Treatments had no effect $(P>0.10)$ on the extent of nutrient digestion in the rumen, whereas replacing GS with RCS in the diet decreased linearly $(P<0.04)$ whole-tract DM, OM, NDF, and N digestibility (Table $3)$.

\section{Ruminal and Whole-Body N Metabolism}

Ruminal balance of total AA was negative for all diets (Supplemental Table S2; http://dx.doi.org/10.3168/ jds.2013-7358). Replacing GS with RCS in the diet progressively lowered $(P<0.05)$ ruminal balance of branched-chain AA (BCAA) and EAA, except for Lys and Met, which were unaffected $(P>0.10)$. Net disappearance of NEAA, Glu, and Pro, was relatively high on all diets, whereas comparisons of intake and flow at the omasum indicated a net synthesis of Ile, Lys, Asp, and Tyr in the rumen (Supplemental Table S2). 
Table 2. Effect of replacing grass silage with red clover silage in the diet on the intake and the flow of nutrients at the omasum, and BCS in lactating cows

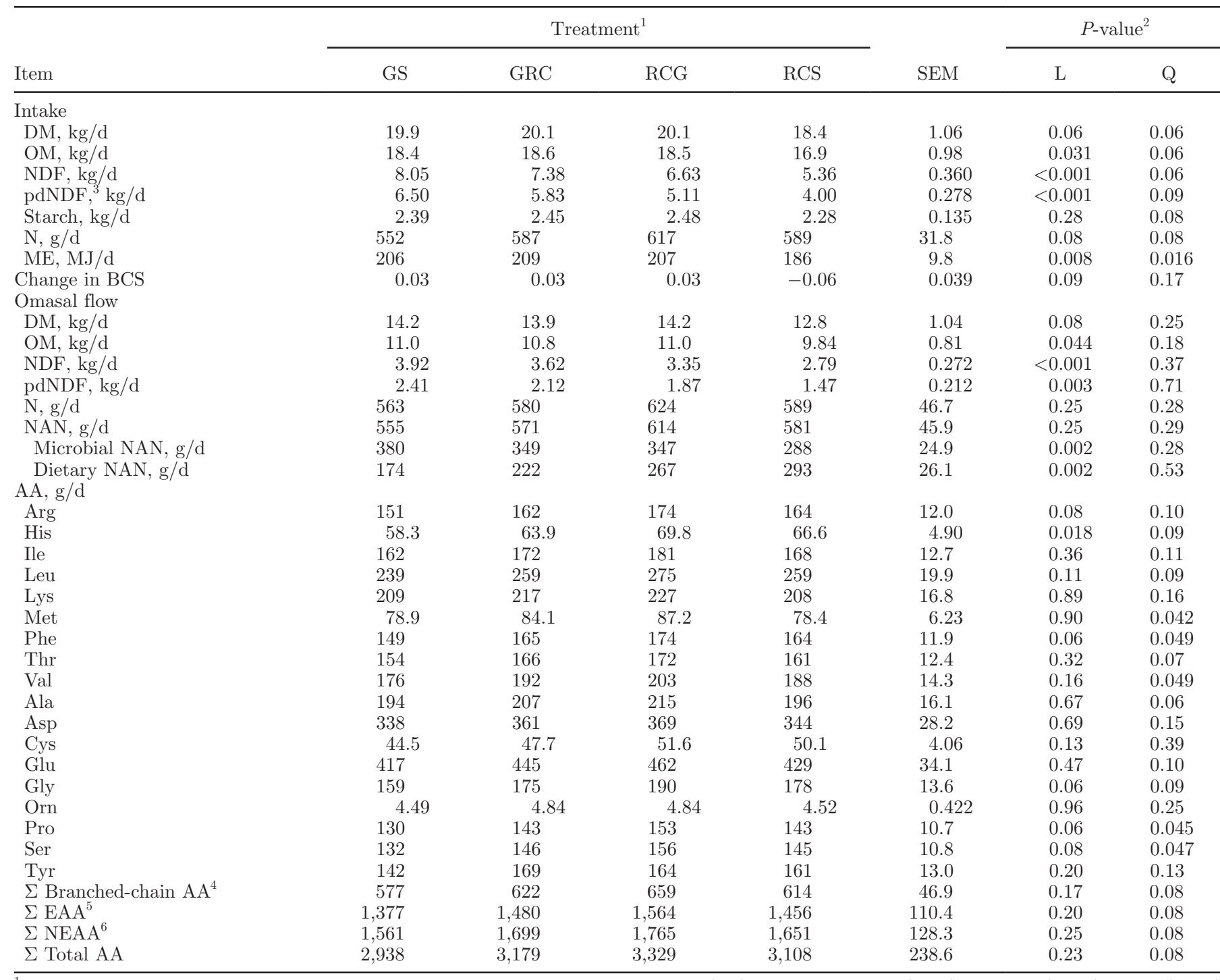

${ }^{1}$ Refers to diets containing a 60:40 forage:concentrate ratio based on grass silage (GS), red clover silage (RCS), or a 2:1 (GRC) or 1:2 (RCG) mixture (DM basis) of GS and RCS, respectively.

${ }^{2}$ Significance of linear (L) and quadratic (Q) components of response to incremental replacement of GS with RCS in the diet.

${ }^{3} \mathrm{pdNDF}=$ potentially digestible NDF.

${ }^{4}$ Sum of Ile, Leu, and Val.

${ }^{5}$ Sum of Arg, His, Ile, Leu, Lys, Met, Phe, Thr, and Val.

${ }^{6}$ Sum of Ala, Asp, Cys, Glu, Gly, Orn, Pro, Ser, and Tyr.

Increases in the proportion of RCS in the diet decreased linearly $(P<0.01)$ protein degradability in the rumen (Table 3). However, the extent of degradation for individual AA also varied according to AA structure (Table 3). Ruminal degradability of His and Pro was particularly high on all diets, whereas the opposite was true for Ile, Lys, and Tyr. Replacing GS with RCS in the diet decreased in a linear or quadratic manner $(P<0.05)$ the degradability of most AA in the rumen, including Met and Cys. Substitution of GS with RCS also tended to lower $(P=0.08)$ the energy efficiency of ruminal microbial protein synthesis (Table 3 ).

Replacing GS with RCS in the diet decreased linearly $(P<0.05) \mathrm{N}$ secretion in milk, increased linearly $(P<$ $0.01)$ fecal $\mathrm{N}$ excretion, and tended to increase $(P=$ 0.07 ) urinary $\mathrm{N}$ excretion (Table 4). Overall, increases in the proportion of RCS in the diet tended to lower $(P$ $=0.08$ ) whole-body $\mathrm{N}$ retention (Table 4 ). 
Table 3. Effect of replacing grass silage with red clover silage in the diet on energy efficiency of microbial protein synthesis in the rumen and ruminal and whole-tract nutrient digestibility coefficients in lactating cows

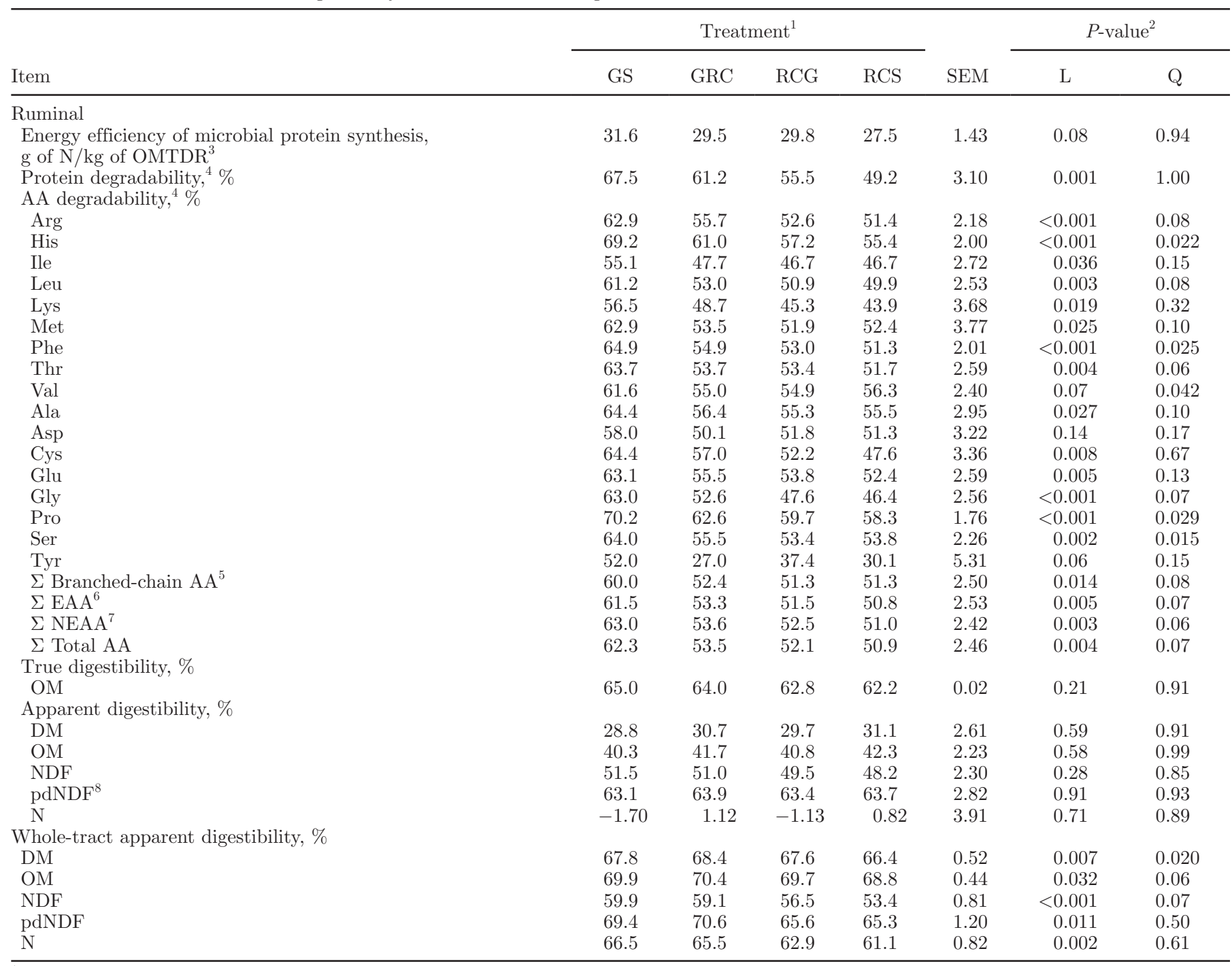

${ }^{1}$ Refers to diets containing a 60:40 forage:concentrate ratio based on grass silage (GS), red clover silage (RCS), or a 2:1 (GRC) or 1:2 (RCG) mixture (DM basis) of GS and RCS, respectively.

${ }^{2}$ Significance of linear (L) and quadratic (Q) components of response to incremental replacement of GS with RCS in the diet.

${ }^{3} \mathrm{OMTDR}=\mathrm{OM}$ truly digested in the rumen.

${ }^{4}$ Calculated taking into account the contribution of microbial $\mathrm{N}$ at the omasum.

${ }^{5} \mathrm{Sum}$ of Ile, Leu, and Val.

${ }^{6}$ Sum of Arg, His, Ile, Leu, Lys, Met, Phe, Thr, and Val.

${ }^{7}$ Sum of Ala, Asp, Cys, Glu, Gly, Orn, Pro, Ser, and Tyr.

${ }^{8} \mathrm{pdNDF}=$ potentially digestible NDF.

\section{Milk Production}

Diets containing both forage species resulted in higher $(P<0.05)$ milk yields compared with either GS or RCS alone (Table 5). Treatments had no influence $(P>0.10)$ on the concentration or secretion of milk fat, whereas milk protein concentration and yield tended to decrease linearly $(P=0.07)$ with increasing RCS in the diet (Table 5). Furthermore, substituting GS with RCS in the diet increased linearly $(P<0.02)$ milk urea and lactose concentrations (Table 5).

\section{Milk FA Composition}

Treatment effects on the composition of major FA in milk are presented in Table 6. A detailed description of treatment effects on monoenoic, octadecadienoic, and odd- and branched-chain FA (OBCFA) are reported 
Table 4. Effect of replacing grass silage with red clover silage in the diet on N partitioning and whole-animal $\mathrm{N}$ balance in lactating cows

\begin{tabular}{|c|c|c|c|c|c|c|c|}
\hline \multirow[b]{2}{*}{ Item } & \multicolumn{4}{|c|}{ Treatment $^{1}$} & \multirow[b]{2}{*}{ SEM } & \multicolumn{2}{|c|}{$P$-value ${ }^{2}$} \\
\hline & GS & GRC & $\mathrm{RCG}$ & RCS & & $\mathrm{L}$ & Q \\
\hline $\mathrm{N}$ balance, $\mathrm{g} / \mathrm{d}$ & 9.62 & 1.67 & 0.29 & -25.4 & 15.61 & 0.08 & 0.45 \\
\hline $\mathrm{N}$ in milk, $\mathrm{g} / \mathrm{d}$ & 145 & 147 & 144 & 137 & 2.2 & 0.039 & 0.11 \\
\hline $\mathrm{N}$ in feces, $\mathrm{g} / \mathrm{d}$ & 185 & 202 & 228 & 230 & 12.9 & 0.003 & 0.34 \\
\hline $\mathrm{N}$ in urine, $\mathrm{g} / \mathrm{d}$ & 212 & 236 & 245 & 247 & 12.6 & 0.019 & 0.22 \\
\hline Partitioning, \% & & & & & & & \\
\hline $\mathrm{N}$ in milk & 26.4 & 25.3 & 23.6 & 23.5 & 1.53 & 0.042 & 0.62 \\
\hline $\mathrm{N}$ in feces & 33.5 & 34.5 & 37.1 & 38.9 & 0.80 & 0.002 & 0.62 \\
\hline $\mathrm{N}$ in urine & 38.4 & 40.4 & 40.0 & 42.0 & 1.60 & 0.07 & 0.98 \\
\hline
\end{tabular}

${ }^{1}$ Refers to diets containing a 60:40 forage:concentrate ratio based on grass silage (GS), red clover silage (RCS), or a 2:1 (GRC) or 1:2 (RCG) mixture (DM basis) of GS and RCS, respectively.

${ }^{2}$ Significance of linear (L) and quadratic (Q) components of response to incremental replacement of GS with RCS in the diet.

in Supplemental Tables S3, S4, and S5, respectively (http://dx.doi.org/10.3168/jds.2013-7358). Replacing GS with RCS in the diet decreased linearly $(P \leq 0.05)$ the proportions of several short- and medium-chain SFA in milk fat (4:0-8:0, 14:0, and 16:0) and increased linearly $(P<0.01) 18: 2 \mathrm{n}-6$ and $18: 3 \mathrm{n}-3$ concentrations (Table 6). However, forage species had no effect $(P>$ $0.05)$ on the total secretion of short- and medium-chain SFA in milk, whereas the output of $18: 2 \mathrm{n}-6$ and $18: 3 \mathrm{n}-$ 3 was increased $(P<0.05)$ in direct relation to RCS in the diet (Supplemental Figure S1; http://dx.doi. org/10.3168/jds.2013-7358). Substituting GS with RCS in the diet increased linearly $(P<0.02)$ the efficiency of 18:2n-6 [from 11 to $15 \%(\mathrm{SE}=1.5)$ ] and 18:3n-3 [from 3 to $9 \%(\mathrm{SE}=0.7)$ ] transfer from the diet into milk, whereas the apparent transfer of both PUFA from the omasum into milk was similar $(P>0.10)$ among treatments, averaging 55 and $54 \%$ for $18: 2 \mathrm{n}-6$ and $18: 3 \mathrm{n}-3$, respectively.
Replacing GS with RCS had no effect $(P>0.10)$ on milk fat 18:0 or cis-9 18:1 concentration, but increased linearly $(P \leq 0.05)$ the abundance of several cis 18:1 $(\Delta 11-16)$ and trans $18: 1(\Delta 6-10,12-16)$ isomers (Table 6; Supplemental Table S3; http://dx.doi.org/10.3168/ jds.2013-7358).

Forage species also resulted in relatively small, albeit often significant, differences in the concentration of 18:2 isomers in milk (Supplemental Table S4; http:// dx.doi.org/10.3168/jds.2013-7358). Replacing GS with RCS increased linearly $(P<0.04)$ cis-9,trans-12 18:2 and $\Delta 9,13$ 18:2 abundance and decreased $(P<0.02)$ trans-9,cis-12 18:2, trans-10,trans-14 18:2, and trans11,trans-15 18:2 concentrations. Treatments had no effect $(P>0.05)$ on milk fat cis-9,trans-11 CLA concentration or secretion, whereas substituting GS for RCS increased linearly $(P \leq 0.05)$ the relative abundance of several minor CLA isomers in milk fat, including trans-7,cis-9 CLA, trans-8,cis-10 CLA, trans-10,cis-12

Table 5. Effect of replacing grass silage with red clover silage in the diet on milk production in lactating cows

\begin{tabular}{|c|c|c|c|c|c|c|c|}
\hline \multirow[b]{2}{*}{ Item } & \multicolumn{4}{|c|}{ Treatment $^{1}$} & \multirow[b]{2}{*}{ SEM } & \multicolumn{2}{|c|}{$P$-value ${ }^{2}$} \\
\hline & GS & GRC & $\mathrm{RCG}$ & $\mathrm{RCS}$ & & $\mathrm{L}$ & $\mathrm{Q}$ \\
\hline \multicolumn{8}{|l|}{ Yield } \\
\hline Milk, kg/d & 27.2 & 28.3 & 28.7 & 27.8 & 0.38 & 0.23 & 0.041 \\
\hline ECM, $\mathrm{kg} / \mathrm{d}$ & 26.9 & 28.9 & 28.2 & 27.5 & 0.64 & 0.74 & 0.08 \\
\hline Fat, g/d & 1,003 & 1,054 & 994 & 1,031 & 73.4 & 0.95 & 0.92 \\
\hline Protein, g/d & 927 & 942 & 918 & 879 & 16.9 & 0.07 & 0.16 \\
\hline Lactose, $\mathrm{g} / \mathrm{d}$ & 1,240 & 1,248 & 1,248 & 1,263 & 5.0 & 0.019 & 0.45 \\
\hline \multicolumn{8}{|l|}{ Concentration } \\
\hline Fat, $\mathrm{g} / \mathrm{kg}$ & 3.83 & 4.02 & 3.79 & 3.94 & 0.280 & 0.95 & 0.92 \\
\hline Protein, $\mathrm{g} / \mathrm{kg}$ & 3.54 & 3.60 & 3.51 & 3.36 & 0.065 & 0.07 & 0.16 \\
\hline Lactose, $\mathrm{g} / \mathrm{kg}$ & 4.73 & 4.76 & 4.76 & 4.82 & 0.042 & 0.019 & 0.47 \\
\hline Urea, mmol/L & 4.32 & 4.65 & 5.26 & 5.41 & 0.227 & 0.010 & 0.70 \\
\hline
\end{tabular}

${ }^{1}$ Refers to diets containing a 60:40 forage:concentrate ratio based on grass silage (GS), red clover silage (RCS), or a 2:1 (GRC) or 1:2 (RCG) mixture (DM basis) of GS and RCS, respectively.

${ }^{2}$ Significance of linear (L) and quadratic (Q) components of response to incremental replacement of GS with RCS in the diet. 
Table 6. Effect of replacing grass silage with red clover silage in the diet on milk fatty acid composition in lactating cows

\begin{tabular}{|c|c|c|c|c|c|c|c|}
\hline \multirow{2}{*}{$\begin{array}{l}\text { FA, } \\
\mathrm{g} / 100 \mathrm{~g} \text { of } \mathrm{FA}\end{array}$} & \multicolumn{4}{|c|}{ Treatment $^{1}$} & \multirow[b]{2}{*}{ SEM } & \multicolumn{2}{|c|}{$P$-value ${ }^{2}$} \\
\hline & GS & GRC & $\mathrm{RCG}$ & $\mathrm{RCS}$ & & $\mathrm{L}$ & Q \\
\hline $4: 0$ & 3.30 & 3.27 & 3.14 & 3.05 & 0.148 & 0.006 & 0.59 \\
\hline $6: 0$ & 2.00 & 1.99 & 1.94 & 1.88 & 0.079 & 0.010 & 0.35 \\
\hline $8: 0$ & 1.22 & 1.22 & 1.20 & 1.18 & 0.041 & 0.019 & 0.47 \\
\hline 10:0 & 2.92 & 2.90 & 2.93 & 2.93 & 0.123 & 0.76 & 0.80 \\
\hline cis-9 10:1 & 0.32 & 0.33 & 0.33 & 0.30 & 0.024 & 0.26 & 0.207 \\
\hline $12: 0$ & 3.59 & 2.56 & 3.61 & 3.62 & 0.139 & 0.67 & 0.72 \\
\hline cis-9 12:1 & 0.10 & 0.10 & 0.10 & 0.09 & 0.006 & 0.47 & 0.47 \\
\hline trans-11 12:1 & 0.09 & 0.09 & 0.09 & 0.08 & 0.006 & 0.17 & 0.33 \\
\hline $14: 0$ & 12.7 & 12.5 & 12.4 & 12.0 & 0.28 & 0.009 & 0.57 \\
\hline cis-9 14:1 & 1.12 & 1.10 & 1.08 & 0.95 & 0.075 & 0.06 & 0.30 \\
\hline trans-9 14:1 & 0.02 & 0.01 & 0.02 & 0.01 & 0.001 & 0.06 & 0.041 \\
\hline $16: 0$ & 33.6 & 33.5 & 33.1 & 32.5 & 0.88 & 0.022 & 0.39 \\
\hline$\Sigma$ cis $16: 1$ & 1.76 & 1.75 & 1.74 & 1.70 & 0.039 & 0.31 & 0.71 \\
\hline$\Sigma$ trans $16: 1$ & 0.30 & 0.31 & 0.30 & 0.34 & 0.012 & 0.027 & 0.16 \\
\hline $18: 0$ & 8.85 & 8.33 & 7.88 & 8.19 & 0.348 & 0.13 & 0.22 \\
\hline cis-9 18:1 & 14.9 & 15.0 & 15.2 & 15.3 & 0.451 & 0.24 & 0.91 \\
\hline$\Sigma$ cis $18: 1$ & 15.8 & 15.9 & 16.2 & 16.4 & 0.49 & 0.13 & 0.84 \\
\hline trans-11 18:1 & 1.05 & 1.12 & 1.06 & 1.15 & 0.047 & 0.10 & 0.52 \\
\hline$\Sigma$ trans $18: 1$ & 2.74 & 2.90 & 2.92 & 3.10 & 0.120 & 0.005 & 0.81 \\
\hline $18: 2 \mathrm{n}-6$ & 1.23 & 1.40 & 1.61 & 1.83 & 0.084 & $<0.001$ & 0.54 \\
\hline$\Sigma 18: 2^{3}$ & 2.18 & 2.42 & 2.64 & 2.86 & 0.115 & $<0.001$ & 0.94 \\
\hline cis-9,trans-11 CLA & 0.51 & 0.56 & 0.56 & 0.57 & 0.037 & 0.30 & 0.68 \\
\hline$\Sigma$ CLA & 0.65 & 0.72 & 0.72 & 0.74 & 0.044 & 0.24 & 0.70 \\
\hline $18: 3 n-3$ & 0.51 & 0.71 & 0.94 & 1.19 & 0.052 & $<0.001$ & 0.33 \\
\hline $18: 3 n-6$ & 0.018 & 0.019 & 0.022 & 0.023 & 0.0013 & 0.011 & 0.86 \\
\hline cis-9,trans-11,cis-15 18:3 & 0.055 & 0.067 & 0.073 & 0.072 & 0.0048 & 0.035 & 0.22 \\
\hline $20: 0$ & 0.16 & 0.17 & 0.18 & 0.20 & 0.006 & $<0.001$ & 0.21 \\
\hline$\Sigma 20: 1$ & 0.22 & 0.24 & 0.25 & 0.27 & 0.009 & 0.003 & 0.73 \\
\hline $20: 2 \mathrm{n}-6$ & 0.02 & 0.02 & 0.03 & 0.03 & 0.002 & $<0.001$ & 0.07 \\
\hline $20: 3 n-3$ & 0.01 & 0.01 & 0.01 & 0.02 & 0.002 & $<0.001$ & 0.21 \\
\hline $20: 3 n-6$ & 0.06 & 0.07 & 0.08 & 0.08 & 0.012 & $<0.001$ & 0.36 \\
\hline $20: 4 n-3$ & 0.05 & 0.05 & 0.06 & 0.06 & 0.007 & 0.002 & 0.90 \\
\hline $20: 4 n-6$ & 0.07 & 0.08 & 0.09 & 0.10 & 0.008 & $<0.001$ & 0.79 \\
\hline $20: 5 n-3^{4}$ & 0.10 & 0.11 & 0.13 & 0.15 & 0.006 & $<0.001$ & 0.91 \\
\hline $22: 0$ & 0.07 & 0.08 & 0.08 & 0.09 & 0.003 & $<0.001$ & 0.20 \\
\hline $22: 2 \mathrm{n}-6$ & 0.004 & 0.004 & 0.005 & 0.005 & 0.0004 & 0.17 & 0.64 \\
\hline $22: 4 n-6$ & 0.011 & 0.012 & 0.014 & 0.014 & 0.0018 & 0.003 & 0.68 \\
\hline $22: 5 n-3$ & 0.07 & 0.07 & 0.08 & 0.09 & 0.008 & 0.005 & 0.78 \\
\hline $22: 6 n-3$ & 0.005 & 0.004 & 0.003 & 0.003 & 0.0003 & 0.012 & 0.09 \\
\hline cis-15 24:1 & 0.02 & 0.02 & 0.01 & 0.01 & 0.001 & $<0.001$ & 0.73 \\
\hline $26: 0$ & 0.03 & 0.03 & 0.02 & 0.01 & 0.001 & $<0.001$ & 0.49 \\
\hline $28: 0$ & 0.005 & 0.005 & 0.004 & 0.004 & 0.0003 & 0.027 & 0.41 \\
\hline$\Sigma$ unidentified FA & 0.41 & 0.43 & 0.45 & 0.46 & 0.018 & 0.048 & 0.77 \\
\hline$\Sigma$ trans $\mathrm{FA}$ & 3.67 & 4.82 & 3.57 & 3.70 & 0.431 & 0.58 & 0.28 \\
\hline$\Sigma \mathrm{SFA}$ & 72.6 & 71.7 & 70.9 & 70.1 & 0.800 & 0.009 & 0.96 \\
\hline$\Sigma$ MUFA & 23.2 & 23.5 & 23.7 & 24.0 & 0.586 & 0.16 & 0.96 \\
\hline$\Sigma$ PUFA & 3.83 & 4.37 & 4.88 & 5.43 & 0.235 & $<0.001$ & 0.98 \\
\hline FA, $\mathrm{g} / 100 \mathrm{~g}$ of fat & 94.0 & 94.0 & 94.0 & 94.0 & 0.034 & 0.85 & 0.57 \\
\hline
\end{tabular}

${ }^{1}$ Refers to diets containing a 60:40 forage:concentrate ratio based on grass silage (GS), red clover silage (RCS), or a 2:1 (GRC) or 1:2 (RCG) mixture (DM basis) of GS and RCS, respectively.

${ }^{2}$ Significance of linear (L) and quadratic (Q) components of response to incremental replacement of GS with RCS in the diet.

${ }^{3}$ Excludes isomers of CLA.

${ }^{4}$ Coelutes with 24:0.

CLA, trans-9,trans-11 CLA, and trans-11,trans-13 CLA (Table 6; Supplemental Table S4 and Supplemental Figure S1; http://dx.doi.org/10.3168/jds.2013-7358).

Treatments also altered the abundance of OBCFA in milk fat (Supplemental Table S5; http://dx.doi. org/10.3168/jds.2013-7358). Substituting GS for RCS increased linearly $(P<0.01) 15: 0,17: 0$, trans $15: 1$ ( $\Delta 5$ and 7 ), cis-9 17:1, and 18-carbon oxygenated FA abundance and decreased linearly $(P \leq 0.05)$ concentrations of several 12- to 17-carbon iso and anteiso FA. However, increases in the proportion of RCS in the diet had no effect $(P>0.10)$ on the concentration (Supple- 
mental Table S5) or secretion (data not presented) of S3,R7,R11,15-tetramethyl-16:0 in milk.

Associations between the flow at the omasum and secretion in milk for specific FA are documented in Figure 1 and Supplemental Table S6 (http://dx.doi. org/10.3168/jds.2013-7358). Across all treatments a close linear relationship existed between the flow at the omasum and secretion in milk for 18:2n-6 and 18:3n-3 $\left(\mathrm{R}^{2}=0.95\right.$ and 1.00, respectively; $P<0.02$; Figure 1$)$. In contrast, associations for the most-abundant 15- and 17-carbon OBCFA were relatively weak $(P>0.10)$, with the exception of iso $15: 0\left(\mathrm{R}^{2}=0.95 ; P<0.02\right)$ and iso 17:0 $\left(\mathrm{R}^{2}=0.73 ; P=0.08\right.$; Supplemental Table S6; http://dx.doi.org/10.3168/jds.2013-7358). Furthermore, a close linear relationship also existed between the flow of NAN and the sum of 13- to 18-carbon OBCFA (collectively 15:0; 17:0; iso 13:0, 14:0, 15:0, 16:0, 17:0, and 18:0; anteiso 13:0, 15:0, and 17:0; $\Sigma 15: 1$; and $\left.\Sigma 17: 1 ; \mathrm{R}^{2}=0.83 ; P=0.06\right)$ at the omasum, but not between the flow of NAN and secretion of OBCFA in milk $\left(\mathrm{R}^{2}=0.30 ; P>0.10\right.$; Supplemental Table S7; http://dx.doi.org/10.3168/jds.2013-7358).

\section{DISCUSSION}

Both experimental silages were well conserved and of high nutritive and fermentation quality as indicated by the low $\mathrm{pH}$, concentration of fermentation acids, and proportions of ammonium $\mathrm{N}$ in total $\mathrm{N}$. Even though the DM content of red clover was lower than grass at the time of ensiling (19 vs. $23 \%$ for red clover and grass swards, respectively), the DM contents of GS and RCS were similar, suggesting higher effluent losses during the ensilage of red clover compared with grass. A higher ash and CP concentration and lower concentration of NDF in RCS compared with GS reflect differences that are typical between ensiled grasses and red clover (Dewhurst et al., 2003b; Lee et al., 2003; Vanhatalo et al., 2009). However, the lower NDF concentration of RCS was not associated with an increase in iNDF concentration compared with GS, which often occurs for red clover grown in Northern Europe (Bertilsson and Murphy, 2003; Kuoppala et al., 2009). It appears that the harvesting of red clover (late-bud stage) at an earlier stage of maturity compared with grass (heading stage) also contributed to the higher $\mathrm{CP}$ and lower NDF concentration of RCS relative to GS.

\section{Nutrient Intake}

Diets based on a mixture of forages resulted in higher DMI compared with either GS or RCS alone, which is in agreement with several earlier reports (Bertilsson and Murphy, 2003; Dewhurst et al., 2003a; Kuoppala et al., 2009). In contrast, other studies indicate the intake potential of RCS to be higher than GS or a mixture of both forages (Dewhurst et al., 2003b; Moorby et al., 2009). The reason for the lower intake of the RCS than GS treatment in the current experiment is not obvious. Concentrations of water-soluble carbohydrates and starch did not differ between ensiled forages, suggesting that other factors were responsible. Differences in herbage composition, extent of fermentation in silo, and digestibility are known to influence the intake potential of forages in lactating cows (Huhtanen et al., 2007; Kuoppala et al., 2009). However, the more extensive fermentation in silo in terms of higher lactic acid concentration for RCS than GS may only partly explain the lower intake of RCS in the present study. In earlier investigations, the intake of RCS was found to be lower than GS, even when both silages were restrictively fermented in the silo and no differences existed in lactic acid concentration between the ensiled forages (Kuoppala et al., 2009; Vanhatalo et al., 2009).

Ruminal pool sizes of DM and NDF have been determined as being lower or similar in cows fed diets based on RCS compared with GS (Bertilsson and Murphy, 2003; Dewhurst et al., 2003a; Kuoppala et al., 2009). In the current experiment, the NDF concentration of RCS was lower than GS, but the extent of nutrient digestion in the rumen was similar among treatments. These observations would tend to suggest that metabolic rather than physical factors limited the intake of the RCS treatment. Even though the regulation of intake involves a complex interaction between numerous factors, evidence exists to suggest that an imbalance or lower bioavailability of AA, or both, may restrict the intake of ensiled red clover harvested at an early stage

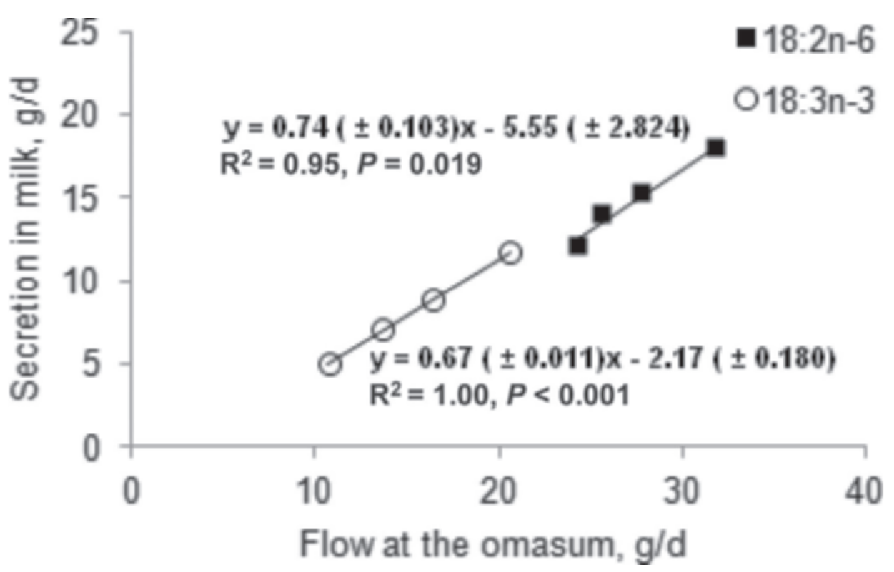

Figure 1. Relationship between the flow at the omasum and secretion in milk for 18:2n-6 and 18:3n-3 in lactating cows fed diets containing a 60:40 forage-to-concentrate ratio based on grass silage, red clover silage, or a mixture of both ensiled forages. Each point represents the treatment mean for $\mathrm{n}=4$ cows. 
of maturity (Vanhatalo et al., 2009). Consistent with the relative ratio of AA to energy being an important determinant of intake potential, the lower intake of the RCS than GS treatment was accompanied by a decrease in the proportion of dietary $\mathrm{N}$ recovered in milk, and an increase in the partitioning of $\mathrm{N}$ intake in feces and urine.

\section{Diet Digestibility}

Despite differences in the NDF and CP concentration of silages, substituting GS for RCS had no major influence on apparent nutrient digestion in the rumen, consistent with the limited differences between these forages species reported previously (Dewhurst et al., 2003a; Vanhatalo et al., 2006). Increases in forage NDF concentration during plant growth are often associated with a decrease in ruminal NDF digestibility (Kuoppala et al., 2010). Even though the NDF concentration of GS was higher than RCS, forage species had no influence on the extent of NDF digestion in the rumen, which may be related to the lower ratio of iNDF to NDF in GS compared with RCS (0.19 vs. 0.27). Grasses and forage legumes are also known to exhibit different ruminal digestion, passage, and comminution kinetics as a consequence of variation in morphology and cellular structures (Wilson and Kennedy, 1996; Rinne and Nykänen, 2000). The passage rate of potentially digestible NDF in the rumen has been reported to be higher in cows fed diets based on RCS than GS (Kuoppala et al., 2009). It therefore appears plausible that the lack of treatment effects on ruminal fiber digestion in the present study was related to the decrease in NDF intake when RCS replaced GS in the diet and a shorter retention time of red clover than grass forage particles in the rumen.

Although forage species had limited effects on ruminal digestion, substituting GS for RCS lowered wholetract $\mathrm{OM}, \mathrm{NDF}$, and $\mathrm{N}$ digestibility, indicating lower availability of nutrients in the small intestine. Previous studies have reported that RCS in the diet has no effect (Bertilsson and Murphy, 2003; Vanhatalo et al., 2006; Kuoppala et al., 2009) or may decrease (Moorby et al., 2009) whole-tract OM and total NDF digestion compared with GS. It is possible that the decrease in wholetract $\mathrm{N}$ digestibility with increased RCS in the diet is related to a higher proportion of AA at the omasum originating from forage protein that has lower bioavailability relative to microbial NAN (Steinshamn, 2010).

\section{Nitrogen Metabolism}

Omasal Flow of NAN. A higher CP concentration of red clover relative to grasses has often been associ- ated with higher postruminal NAN flow, principally through greater ruminal escape of dietary protein, and to a lesser extent microbial NAN (Dewhurst et al., 2003a; Vanhatalo et al., 2006, 2009). Forage species had no effect on NAN at the omasum, such that the higher escape of dietary protein on RCS-containing diets compensated for a decrease in microbial protein synthesis compared with GS. In the present experiment, red clover was harvested at a relatively early growth stage, although microbial NAN at the omasum can be increased when red clover is harvested at a later stage of growth, due to a higher DMI potential (Vanhatalo et al., 2009). Often, ruminal microbial protein synthesis has been reported energetically more efficient in cows fed RCS compared with GS (Dewhurst et al., 2003a; Vanhatalo et al., 2006, 2009), whereas the reverse was true in the present study. Overall, the increases in net ruminal AA degradation (Supplemental Table S2; http://dx.doi. org/10.3168/jds.2013-7358), in addition to a lower DMI and higher lactic acid concentration during ensiling, suggests that the supply of energy, rather than AA, constrained the synthesis of microbial protein in the rumen when RCS replaced GS in the diet.

Higher escape of dietary $\mathrm{N}$ from the rumen and decreases in total-tract $\mathrm{N}$ digestibility when RCS replaced GS in the diet may be related to the inherent differences in PPO activity between forages, but the underlying mechanism and mode of action remains uncertain (Lee et al., 2004; Lourenço et al., 2008; Van Ranst et al., 2011). Previous studies have also reported that compared with grasses, the protein of RCS is inherently less degradable in the rumen (Dewhurst et al., 2003a; Vanhatalo et al., 2006, 2009). Recent reports suggest that the higher fecal $\mathrm{N}$ output for diets containing RCS is not related to greater excretion of particle-associated $\mathrm{CP}$, but more likely to be explained by incomplete digestion (Huhtanen et al., 2014).

Red clover has an inherently higher activity of PPO than grasses, a stress-activated enzyme that catalyzes the oxidation of phenols and diphenols to quinones, which will readily react with nucleophilic binding sites (Igarashi and Yasui, 1985). Such binding sites can be found on sulfur-containing AA, resulting in the formation of protein-bound phenols that may serve as a physical barrier to digestive enzymes (Van Ranst et al., 2011). It might, therefore, be expected that the flow of bound phenols at the omasum would be increased when RCS replaced GS in the diet, but forage species had no influence on the amounts of these compounds escaping the rumen (Halmemies-Beauchet-Filleau et al., 2013c).

Although the net disappearance of sulfur-containing AA Met and Cys in the rumen did not differ between forage species (Supplemental Table S2; http://dx.doi. org/10.3168/jds.2013-7358), RCS in the diet progres- 
sively lowered ruminal Met and Cys degradability from 63 to $52 \%$ and from 64 to $48 \%$, respectively. Furthermore, the decrease in ruminal degradability of Cys ( -17 percentage units) to RCS in the diet was higher compared with that of total AA ( -11 percentage units), which is consistent with a possible role of PPO in protecting sulfur-containing AA from metabolism in the rumen.

It is also possible that differences in ruminal digestion kinetics offer an explanation for the effects of forage species on ruminal protein degradation. Diets based on RCS alone or as a mixture with GS have in some (Bertilsson and Murphy, 2003; Bayat et al., 2010), but not in all cases (Dewhurst et al., 2003a), been demonstrated to alter particle size distribution in the rumen, in particular by increasing the proportion of very small particles $(<0.038 \mathrm{~mm}$; Bayat et al., 2010) capable of escaping the rumen.

Omasal Flow of A A. Replacing GS with RCS had no major effect on the postruminal supply of AA in the present work, whereas earlier studies reported higher flows of all AA with RCS relative to GS, other than for Met and Cys, which were unaffected by forage species (Vanhatalo et al., 2009). Diets based on a mixture of GS and RCS increased the flow of most AA at the omasum that paralleled the improvements in DMI. Positive production responses to rumen-protected AA and intravenous or postruminal infusions of AA serve to highlight the importance of the balance of absorbed AA on lactational performance (Schwab et al., 1992; Vanhatalo et al., 1999; Robinson, 2010). Some evidence exists that Met is the first-limiting AA when RCS replaces GS in diets supplemented with cereal-based concentrate containing rapeseed meal (Vanhatalo et al., 2009). Even though diets based on both GS and RCS increased Met at the omasum compared with either forage alone, the relative proportions of Met progressively decreased as the amount of RCS in the diet increased (from 2.7 to $2.5 \mathrm{~g} / 100 \mathrm{~g}$ of total AA). Replacing GS with RCS is also known to decrease the transfer of Met from the small intestine into plasma (Vanhatalo et al., 2009) and the availability of Met for absorption (Lee et al., 2009). In maize silage-based diets, Lys is often rate limiting for milk protein synthesis (Schwab et al., 1992). In the present study, RCS in the diet progressively decreased the Lys concentration of omasal digesta from 7.1 to $6.7 \mathrm{~g} / 100 \mathrm{~g}$ of total AA, which can be attributed to the lower Lys concentration of RCS relative to GS as well as less net synthesis of Lys in the rumen. For all diets, the flow of Lys at the omasum exceeded intake, on average, by 7 to $12 \%$, providing further evidence that rumen bacteria and protozoa are capable of EAA synthesis (Onodera, 1986; El-Waziry, 2012).
Nitrogen Partitioning. Whole-body N balance was positive on all diets, other than when RCS was fed alone. Differences in BCS across treatments also suggest that body reserves were used to support milk production for the RCS diet. These findings may be related to lower bioavailability of AA with the RCS treatment, as indicated by the lower whole-tract $\mathrm{N}$ digestibility and a possible imbalance of AA available for absorption compared with diets containing GS. The effects of forage species on $\mathrm{N}$ retention in lactating cows are, however, inconsistent. Replacing GS with RCS in the diet has been shown to have no effect (Bertilsson and Murphy, 2003; Moorby et al., 2009) or marginally improve (Lee et al., 2009; Vanhatalo et al., 2009) whole-body $\mathrm{N}$ balance. This may be related to differences in the genetic merit and production potential of the animal, quality of the silage fed, and the forage-to-concentrate ratio used within the studies.

Replacing GS with RCS lowered the conversion of dietary $\mathrm{N}$ into milk $\mathrm{N}$ from 26.4 to $23.5 \%$, which represents a typical response for lactating cows (Dewhurst et al., 2003b; Moorby et al., 2009; Vanhatalo et al., 2009). A lower recovery of $\mathrm{N}$ in milk was accompanied by increased partitioning of $\mathrm{N}$ into urine and feces, in agreement with earlier reports (Lee et al., 2009; Vanhatalo et al., 2009).

\section{Milk Production}

Feeding GS and RCS as a mixture increased milk yield compared with GS or RCS as the sole forage, which reflected the higher DMI of diets containing both forages. Diets based on a mixture of GS and RCS have, in some cases, been shown to improve milk yield compared with either forage alone (Moorby et al., 2009), whereas in others, milk yield has been increased in direct response to RCS in the diet (Dewhurst et al., 2003b; Steinshamn, 2010). Despite a lower DM and ME intake for RCS $(-1.5 \mathrm{~kg} / \mathrm{d}$ and $-20 \mathrm{MJ} / \mathrm{d}$, respectively) relative to GS, the ECM yield was higher $(+0.6 \mathrm{~kg} / \mathrm{d})$, indicating an improved apparent conversion of dietary energy into milk when RCS was fed as the sole forage, which is in agreement with earlier reports (Vanhatalo et al., 2009). However, improvements in energy utilization for milk production may be more apparent than true, considering the implicated higher use of body reserves in cows fed RCS.

Replacing GS with RCS in the diet increased linearly the secretion of lactose in milk, which can be attributed to the higher lactic acid concentration of RCS relative to GS and associated with increases in ruminal molar propionate proportions (Halmemies-Beauchet-Filleau et al., 2013c). 
Often, replacing GS with RCS lowers milk fat concentration, which has been attributed to decreases in 2:0 and 4:0 availability (Steinshamn, 2010). Even though RCS in the diet progressively decreased the molar ratio of lipogenic to glucogenic VFA in the rumen and increased 18:2n-6 and 18:3n-3 at the omasum (Halmemies-Beauchet-Filleau et al., 2013c), these changes were not associated with alterations in the secretion of 4- to 16-carbon SFA in milk or milk fat output.

Despite a marginally higher $\mathrm{N}$ intake of cows fed a mixture of both forages, RCS tended to lower milk protein concentration and secretion, which appears to be related to decreases in microbial protein supply and lower AA bioavailability in the small intestine. In some studies, RCS has increased milk protein yield compared with GS (Bertilsson and Murphy, 2003, yr 1; Dewhurst et al., 2003b; Vanhatalo et al., 2006) but not in all cases (Bertilsson and Murphy, 2003, yr 2; Vanhatalo et al., 2009).

\section{Milk FA}

cis-9 18:1, 18:2n-6, and 18:3n-3. Consistent with earlier reports, substituting GS for RCS in the diet increased milk fat 18:2n-6 and 18:3n-3 concentration (Dewhurst et al., 2006; Vanhatalo et al., 2007; Moorby et al., 2009). However, the enrichment of PUFA in milk fat was not solely explained by differences in 18:2n6 and 18:3n-3 intake between forage species (108 and 160 vs. 120 and 133 for GS and RCS, respectively; Halmemies-Beauchet-Filleau et al., 2013c). Replacing GS with RCS in the diet progressively increased the output of $18: 2 \mathrm{n}-6$ and $18: 3 \mathrm{n}-3$ in milk in direct relation to increases in the flows of these PUFA at the omasum (from 24 to 32 and from 11 to $21 \mathrm{~g} / \mathrm{d}$, respectively; Halmemies-Beauchet-Filleau et al., 2013c). A similar efficiency of transfer of 18-carbon PUFA from the omasum into milk among treatments also suggests that forage species does not substantially alter the bioavailability of PUFA in the small intestine of lactating cows. Forage species had limited influence on milk fat cis-9 18:1 concentrations consistent with the similar flow of 18:0 and cis-9 18:1 at the omasum across treatments (Halmemies-Beauchet-Filleau et al., 2013c) and earlier comparisons (Lee et al., 2009), whereas in other studies RCS has been reported to increase milk fat cis-9 18:1 concentration (Vanhatalo et al., 2007; Moorby et al., 2009).

Short- and Medium-Chain SFA. Replacing GS with RCS in the diet decreased linearly the proportions of several short- and medium-chain SFA in milk fat (4:0-8:0, 14:0, and 16:0). Several studies have reported that RCS decreases milk fat 14:0 and 16:0 concentrations (Dewhurst et al., 2003b, experiment 2; Vanhatalo et al., 2007; Moorby et al., 2009), but not in all cases (Dewhurst et al., 2003b, experiment 1; Steinshamn, 2010). Long-chain FA containing 16 or more carbon atoms inhibit synthesis of short- and medium-chain SFA de novo in the mammary glands of ruminants, with the effects being more potent for FA with a longer carbon chain or higher degree of unsaturation, or both (Shingfield et al., 2010). Daily secretion of 4- to 16-carbon SFA in milk was unaffected by treatment, despite progressive increases in PUFA at the omasum to RCS in the diet (from 46 to $65 \mathrm{~g} / \mathrm{d}$; HalmemiesBeauchet-Filleau et al., 2013c). Decreases in milk fat concentration of short- and medium-chain SFA for RCS diets relative to GS in the current study was due to increased incorporation of preformed FA into milk triacylglycerols, rather than an overall decrease in the synthesis of SFA de novo.

Nonconjugated 18:2 and 18:3 Intermediates of Biohydrogenation. Inclusion of RCS in the diet enriched cis-9,trans-11,cis-15 18:3 and lowered trans11,trans-15 18:2 concentrations in milk, which reflected the influence of forage species on the flow of these biohydrogenation intermediates at the omasum (Halmemies-Beauchet-Filleau et al., 2013c). It is possible that a proportion of cis-9,trans-11,cis-15 18:3 in milk could originate from the action of stearoyl-CoA desaturase on trans-11,cis-15 18:2 in the mammary gland. Across all treatments, the flow of trans-11,cis-15 18:2 at the omasum was only moderately associated with cis-9,trans-11,cis-15 18:3 secretion in milk, with the regression having a slope 3 times lower compared with cis-9,trans-11,cis-15 18:3 at the omasum. Overall, evidence from this and earlier studies (Lerch et al., 2012) do not support endogenous synthesis as a major source of cis-9,trans-11,cis-15 18:3 in bovine milk.

$\boldsymbol{C L} \boldsymbol{A}$. Replacing GS with RCS in the diet had no effect on milk fat cis-9,trans-11 CLA concentration, consistent with earlier findings (Dewhurst et al., 2003b;Vanhatalo et al., 2007; Lee et al., 2009), but progressively increased the abundance of trans- 7 , cis- 9 CLA, trans-10,cis-12 CLA, and trans-11,trans-13 CLA, as reported previously (Vanhatalo et al., 2007).

Secretion of trans-10,cis-12 CLA in milk increased in direct response to RCS in the diet (from 7.3 to 14 $\mathrm{mg} / \mathrm{d}$ ), despite decreases in trans-10, cis-12 CLA at the omasum from 160 to $110 \mathrm{mg} / \mathrm{d}$ (Halmemies-BeauchetFilleau et al., 2013c). These findings may be related to forage species influencing the absorption or the partitioning of trans-10,cis-12 CLA between different tissues.

18:1. Red clover silage in the diet resulted in the enrichment of several cis-18:1 $(\Delta 11-16)$ and trans-18:1 $(\Delta 6-10,12-16)$ in milk fat that originate from biohydrogenation of 18-carbon unsaturates in the rumen 
(Shingfield et al., 2010), but the magnitude of these increases were rather small, consistent with earlier observations (Vanhatalo et al., 2007). Comparison of the flow at the omasum and secretion in milk offered no support that the efficiency of trans $(\Delta 4-8,10-16)$ or cis $(\Delta 11,12$, and 16$) 18: 1$ isomer transfer from the omasum into milk of 39 to $88 \%$ differed due to forage species. However, the efficiency of transfer of trans-9 18:1, cis-13 18:1, and cis-15 18:1 were much higher (94, 170 , and $98 \%$, respectively) suggesting that chain elongation or oxidation, or both, in nonmammary tissues may contribute to the secretion of these FA in milk fat.

$\boldsymbol{O B C F A}$. Forage species altered the relative distribution and abundance of OBCFA in milk fat. Inclusion of RCS in the diet enhanced linearly milk fat 15:0 and 17:0 concentration, whereas concentrations of iso 15:0 and iso 17:0 were decreased, as demonstrated in earlier studies (Dewhurst et al., 2003b; Vanhatalo et al., 2007; Moorby et al., 2009). However, differences in the flow of 15:0 and 17:0 at the omasum were not reflected as changes in the secretion of these FA in milk. In addition to rumen microbes, 15:0 and 17:0 in milk may also originate from synthesis de novo in adipose and the mammary glands using propionate as a precursor (Vlaeminck et al., 2006). Consistent with synthesis in ruminant tissues, the secretion of 15:0 and 17:0 in milk exceeded flow at the omasum, on average, by 67 and $53 \%$, respectively, which is in agreement with earlier investigations (Dewhurst et al., 2007; HalmemiesBeauchet-Filleau et al., 2013a,b).

Across treatments, a close positive association existed between the flow of microbial NAN and the sum of 13- to 18-carbon OBCFA at the omasum. However, secretion of total 13- to 18-carbon OBCFA in milk was poorly correlated with the flows of NAN or OBCFA at the omasum, although a positive relation was identified between the flow and secretion for iso 15:0 and iso 17:0 in milk. It has been suggested that the amount of iso 15:0 and iso 17:0 in ruminal contents could serve as a marker of Ruminococcus flavefaciens and Butyrivibrio fibrisolvens populations (Vlaeminck et al., 2006), the latter exhibiting phospholipatic activity and thought responsible for the biohydrogenation of unsaturated FA in the rumen (Lourenço et al., 2010). Recent studies have shown that replacing GS with RCS alters the diversity and abundance of ruminal bacteria capable of lipid metabolism (Huws et al., 2010), which may explain, at least in part, differences in milk fat OBCFA concentrations due to forage species. However, the output of iso 17:0 in milk exceeded the flow at the omasum by, on average, $92 \%$, confirming substantial postruminal synthesis (Vlaeminck et al., 2006; Dewhurst et al., 2007). Overall, the strength of the associations between flows at the omasum and secretion in milk did not support measurements of milk OBCFA as a marker of microbial protein supply in lactating cows, with the possible exception of iso 15:0.

\section{CONCLUSIONS}

Diets based on a mixture of RCS and GS stimulated higher DMI and milk yields compared with either forage alone when offered as part of a TMR with a 60:40 forage-to-concentrate DM ratio. Forage species had no effect on NAN at the omasum, with increases in ruminal escape of dietary protein compensating for lowered microbial protein synthesis when RCS replaced GS. Furthermore, RCS increased the partitioning of dietary $\mathrm{N}$ in feces and urine and lowered $\mathrm{N}$ secretion in milk. A less efficient utilization of $\mathrm{N}$ for milk protein synthesis on diets containing RCS appeared to be associated with lower bioavailability of AA and a possible imbalance between AA supply and requirements for milk protein synthesis. Substituting GS for RCS in the diet enriched milk fat 18:2n-6 and 18:3n-3 concentrations, with no evidence of differences in the bioavailability of PUFA or synthesis of 4- to 16-carbon SFA de novo in the mammary glands due to forage species. For all diets, a substantial proportion of 15:0, 17:0, and iso 17:0 secreted in milk was synthesized endogenously.

\section{ACKNOWLEDGMENTS}

The authors gratefully acknowledge the contribution of staff at the Metabolism Unit of MTT Agrifood Research Finland (Jokioinen, Finland) for the care of experimental animals and the collection of experimental samples under the supervision of Laila Hakkarainen and chemical analysis undertaken in the MTT laboratory under the guidance of Taina Jalava. This work was supported in part by the Finnish Funding Agency for Technology and Innovation (Helsinki, Finland), Valio Ltd. (Helsinki, Finland), Raisio Feed Ltd. (Raisio, Finland), and Kemira Ltd. (Helsinki, Finland), and a $\mathrm{PhD}$ studentship from the Raisio Science Foundation (Raisio, Finland).

\section{REFERENCES}

Ahvenjärvi, S., A. Vanhatalo, P. Huhtanen, and T. Varvikko. 2000. Determination of reticulo-rumen and whole-stomach digestion in lactating cows by omasal canal or duodenal sampling. Br. J. Nutr. $83: 67-77$.

Bayat, A., M. Rinne, K. Kuoppala, S. Ahvenjärvi, A. Vanhatalo, and P. Huhtanen. 2010. Ruminal large and small particle kinetics in dairy cows fed red clover and grass silages harvested at two stages of growth. Anim. Feed Sci. Technol. 155:86-98.

Bertilsson, J., and M. Murphy. 2003. Effects of feeding clover silages on feed intake, milk production and digestion in dairy cows. Grass Forage Sci. 58:309-322. 
Dewhurst, R. J., R. T. Evans, N. D. Scollan, J. M. Moorby, R. J. Merry, and R. J. Wilkins. 2003a. Comparison of grass and legume silages for milk production. 2. In vivo and in sacco evaluations of rumen function. J. Dairy Sci. 86:2612-2621.

Dewhurst, R. J., W. J. Fisher, J. K. S. Tweed, and R. J. Wilkins. 2003b. Comparison of grass and legume silages for milk production. 1. Production responses with different levels of concentrate. J. Dairy Sci. 86:2598-2611.

Dewhurst, R. J., J. M. Moorby, B. Vlaeminck, and F. Fievez. 2007. Apparent recovery of duodenal odd- and branched-chain fatty acids in milk of dairy cows. J. Dairy Sci. 90:1775-1780.

Dewhurst, R. J., K. J. Shingfield, M. R. F. Lee, and N. D. Scollan. 2006. Increasing the concentrations of beneficial fatty acids in milk produced by dairy cows in high-forage systems. Anim. Feed Sci. Technol. 131:168-206.

El-Waziry, A. M. 2012. Synthesis of diaminopimelic acid, lysine and pipecolic acid from spartic acid by rumen microorganism. J. Anim. Vet. Adv. 11:2038-2042.

Esala, M. 1991. Split application of nitrogen: Effects on the protein in spring wheat and fate of ${ }^{15} \mathrm{~N}$-labelled nitrogen in the soil-plant system. Ann. Agric. Fenniae 30:219-309.

European Commission. 1998. Commission Directive $98 / 64 / \mathrm{EC}$ of 3 September 1998 establishing Community methods of analysis for the determination of amino acids, crude oils and fats, and olaquindox in feedingstuffs and amending Directive 71/393/EEC. Off. J. L 257, 19/09/1998:0014-0028. European Commission, Brussels, Belgium.

Gebauer, S. K., T. L. Psota, W. S. Harris, and P. M. Kris-Etherton. 2006. n-3 fatty acid dietary recommendations and food sources to achieve essentiality and cardiovascular benefits. Am. J. Clin. Nutr. 83:1526S-1535S

Halmemies-Beauchet-Filleau, A., P. Kairenius, S. Ahvenjärvi, L. K. Crosley, S. Muetzel, P. Huhtanen, A. Vanhatalo, V. Toivonen, R. J. Wallace, and K. J. Shingfield. 2013a. Effect of forage conservation method on ruminal lipid metabolism and microbial ecology in lactating cows fed diets containing a 60:40 forage-to-concentrate ratio. J. Dairy Sci. 96:2428-2447.

Halmemies-Beauchet-Filleau, A., P. Kairenius, S. Ahvenjärvi, V Toivonen, P. Huhtanen, A. Vanhatalo, D. I. Givens, and K. J. Shingfield. 2013b. Effect of forage conservation method on plasma lipids, mammary lipogenesis, and milk fatty acid composition in lactating cows fed diets containing a 60:40 forage-to-concentrate ratio. J. Dairy Sci. 96:5267-5289.

Halmemies-Beauchet-Filleau, A., T. Kokkonen, A.-M. Lampi, V. Toivonen, K. J. Shingfield, and A. Vanhatalo. 2011. Effect of plant oils and camelina expeller on milk fatty acid composition in lactating cows fed diets based on red clover silage. J. Dairy Sci. 94:4413-4430.

Halmemies-Beauchet-Filleau, A., A. Vanhatalo, V. Toivonen, T. Heikkilä, M. R. F. Lee, and K. J. Shingfield. 2013c. Effect of replacing grass silage with red clover silage on ruminal lipid metabolism in lactating cows fed diets containing a 60:40 forage-to-concentrate ratio. J. Dairy Sci. 96:5882-5900.

Huhtanen, P., A. Bayat, S. J. Krizsan, and A. Vanhatalo. 2014. Compartmental flux and in situ methods underestimate total feed $\mathrm{N}$ as judged by omasal sampling due to ignoring soluble feed N flow. Br. J. Nutr. 111:535-546. http://dx.doi.org/10.1017/ S0007114513002651.

Huhtanen, P., M. Rinne, and J. Nousiainen. 2007. Evaluation of the factors affecting silage intake in cows: A revision of the relative silage dry-matter intake index. Animal 1:758-770.

Huws, S. A., M. R. F. Lee, S. M. Muetzel, M. B. Scott, and R. J. Wallace. 2010. Forage type and fish oil causes shifts in rumen bacterial diversity. FEMS Microbiol. Ecol. 73:396-407.

Igarashi, K., and T. Yasui. 1985. Oxidation of free methionine and methionine residues in protein involved in the browning reaction of phenolic compounds. Agric. Biol. Chem. 49:2309-2315.

Korhonen, M., S. Ahvenjärvi, A. Vanhatalo, and P. Huhtanen. 2002. Supplementing barley or rapeseed meal to dairy cows fed grassred clover silage: II. Amino acid profile of microbial fractions. J. Anim. Sci. 80:2188-2196.
Kuoppala, K., S. Ahvenjärvi, M. Rinne, and A. Vanhatalo. 2009. Effects of feeding grass or red clover silage cut at two maturity stages in dairy cows. 2. Dry matter intake and cell wall digestion kinetics. J. Dairy Sci. 92:5634-5644.

Kuoppala, K., M. Rinne, S. Ahvenjärvi, J. Nousiainen, and A. Vanhatalo. 2010. The effect of harvesting strategy of grass silage on digestion and nutrient supply in dairy cows. J. Dairy Sci. 93:3253-3263.

Lee, M. R. F., L. J. Harris, R. J. Dewhurst, R. J. Merry, and N. D. Scollan. 2003. The effect of clover silages on long chain fatty acid rumen transformations and digestion in beef steers. Anim. Sci. 76:491-501.

Lee, M. R. F., V. J. Theobald, J. K. S. Tweed, A. L. Winters, and N. D. Scollan. 2009. Effect of feeding fresh or conditioned red clover on milk fatty acids and nitrogen utilization in lactating dairy cows. J. Dairy Sci. 92:1136-1147.

Lee, M. R. F., A. L. Winters, N. D. Scollan, R. J. Dewhurst, M. K. Theodorou, and F. R. Minchin. 2004. Plant mediated lipolysis and proteolysis in red clover with different polyphenol oxidase activities. J. Sci. Food Agric. 84:1639-1645.

Lerch, S., K. J. Shingfield, A. Ferlay, A. Vanhatalo, and Y. Chilliard. 2012. Rapeseed or linseed in grass-based diets: Effects on conjugated linoleic and conjugated linolenic acid isomers in milk fat from Holstein cows over 2 consecutive lactations. J. Dairy Sci. 95:7269-7287.

Lourenço, M., E. Ramos-Morales, and R. J. Wallace. 2010. The role of microbes in rumen lipolysis and biohydrogenation and their manipulation. Animal 4:1008-1023.

Lourenço, M., G. Van Ranst, B. Vlaeminck, S. De Smet, and V. Fievez. 2008. Influence of different dietary forages on the fatty acid composition of rumen digesta as well as ruminant meat and milk. Anim. Feed Sci. Technol. 145:418-437.

Merry, R. J., M. R. F. Lee, D. R. Davies, R. J. Dewhurst, J. M. Moorby, N. D. Scollan, and M. K. Theodorou. 2006. Effect of high-sugar ryegrass silage and mixtures with red clover silage on ruminant digestion. 1. In vitro and in vivo studies of nitrogen utilization. J. Anim. Sci. 84:3049-3060.

Ministry of Agriculture, Fisheries and Food. 1975. Energy allowances and feeding systems for ruminants. Technical Bulletin 33. Ministry of Agriculture, Fisheries and Food, London, UK.

Moorby, J. M., M. R. F. Lee, D. R. Davies, E. J. Kim, G. R. Nute, N. M. Ellis, and N. D. Scollan. 2009. Assessment of dietary ratios of red clover and grass silages on milk production and milk quality in dairy cows. J. Dairy Sci. 92:1148-1160.

Onodera, R. 1986. Contribution of protozoa to lysine synthesis in the in vitro rumen microbial ecosystem. Appl. Environ. Microbiol. 51:1350-1351.

Rinne, M., and A. Nykänen. 2000. Timing of primary growth harvest affects the yield and nutritive value of timothy-red clover mixtures. Agric. Food Sci. Finland 9:121-134.

Robinson, P. H. 2010. Impacts of manipulating ration metabolizable lysine and methionine levels on the performance of lactating dairy cows: A systematic review of the literature. Livest. Sci. 127:115126

Salo, M.-L., and M. Salmi. 1968. Determination of starch by the amyloglucosidase method. J. Sci. Agric. Soc. Finland 40:38-45.

Schwab, C. G., C. K. Bozak, N. L. Whitehouse, and M. M. A. Mesbah. 1992. Amino acid limitation and flow to duodenum at four stages of lactation. 1. Sequence of lysine and methionine limitation. J. Dairy Sci. 75:3486-3502.

Shingfield, K. J., L. Bernard, C. Leroux, and Y. Chilliard. 2010. Role of trans fatty acids in the nutritional regulation of mammary lipogenesis in ruminants. Animal 4:1140-1166.

Shingfield, K. J., M. Bonnet, and N. D. Scollan. 2013. Recent developments in altering the fatty acid composition of ruminant derived foods. Animal 7(Suppl. 1):132-162.

Shingfield, K. J., Y. Chilliard, V. Toivonen, P. Kairenius, and D. I. Givens. 2008. Trans fatty acids and bioactive lipids in ruminant milk. Pages 3-65 in Bioactive components of milk, Advances in Experimental Medicine and Biology. Vol. 606. Z. Bösze, ed. Springer, New York, NY. 
Shingfield, K. J., S. Jaakkola, and P. Huhtanen. 2002. Effect of forage conservation method, concentrate level and propylene glycol on intake, feeding behaviour and milk production of dairy cows. Anim. Sci. 74:383-397.

Steinshamn, H. 2010. Effect of forage legumes on feed intake, milk production and milk quality-A review. Anim. Sci. Pap. Rep. 28:195-206.

Van Ranst, G., M. R. F. Lee, and V. Fievez. 2011. Red clover polyphenol oxidase and lipid metabolism. Animal 5:512-521.

Vanhatalo, A., T. Gäddnäs, and T. Heikkilä. 2006. Microbial protein synthesis, digestion and lactation responses of cows to grass or grass-red clover silage supplemented with barley or oats. Agric. Food Sci. 15:252-267.

Vanhatalo, A., P. Huhtanen, V. Toivonen, and T. Varvikko. 1999. Response of dairy cows fed grass silage diets to abomasal infusions of histidine alone or in combination with methionine and lysine. J. Dairy Sci. 82:2674-2685.
Vanhatalo, A., K. Kuoppala, S. Ahvenjärvi, and M. Rinne. 2009. Effects of feeding grass or red clover silage cut at two maturity stages in dairy cows. 1 . Nitrogen metabolism and supply of amino acids. J. Dairy Sci. 92:5620-5633.

Vanhatalo, A., K. Kuoppala, V. Toivonen, and K. J. Shingfield. 2007. Effect of forage species and stage of maturity on bovine milk fatty acid composition. Eur. J. Lipid Sci. Technol. 109:856-867.

Vlaeminck, B., V. Fievez, A. R. J. Cabrita, A. J. M. Fonseca, and R. J. Dewhurst. 2006. Factors affecting odd- and branched-chain fatty acids in milk: A review. Anim. Feed Sci. Technol. 131:389-417.

Wilson, J. R., and P. M. Kennedy. 1996. Plant and animal constrains to voluntary feed intake associated with fibre characteristics and particle breakdown and passage in ruminants. Aust. J. Agric. Res. 47:199-225. 